\title{
Characterization of Boar Studs in Brazil
}

\section{Paulo Eduardo Bennemann ${ }^{1}$ (D) José Francisco Manta Bragança ${ }^{1}$ (D) Marina Patricia Walter ${ }^{1}$ (D) Juliano Bottan ${ }^{2}$ Sérgio Abreu Machado ${ }^{1 *}$ (D)}

\author{
${ }^{1}$ Departamento de Medicina Veterinária, Universidade do Oeste de Santa Catarina (UNOESC), 89820-000, Xanxerê, SC, Brasil. E-mail \\ sergio.machado@unoesc.edu.br. "Corresponding author. \\ ${ }^{2}$ Programa de Pós-graduação em Medicina Veterinária, Universidade do Oeste de Santa Catarina (UNOESC), Xanxerê, SC, Brasil.
}

\begin{abstract}
Understanding the flow of processes in swine production systems and how they work is fundamental to improving reproductive performance. We surveyed 32 boar studs in Brazil, representing $61.53 \%$ of the total in the country. Commercial lines were the most common breed (59.38\%) used in the studs. Individual pens and stalls were the most commonly used as housing system (71.9\%), and $81.25 \%$ of the studs reported having some form of thermal control system. For most of the studs (62.51\%), average weekly sperm concentration was higher than 200 million cells per $\mathrm{mL}$. Also, for most studs (71.88\%) average weekly ejaculate volume was more than $250 \mathrm{~mL}$. In $46.88 \%$ of the studs each ejaculate yielded 26 to 40 semen doses. In 6.25\% of the studs, 3.5 billion sperm cells per dose were used for artificial, intracervical insemination. Sperm concentration in $46.88 \%$ of the studs was determined using a computer-assisted system analysis. The assessment of sperm quality was conducted using morphology, concentration, and microbiological testing. Employees working on semen collection had formal education of elementary/ middle school (34.38\%) and high school (37.5\%). Most of the laboratory technicians had frequented high school (75\%). The most time-consuming task was semen processing, taking 16 to $25 \mathrm{~h}$ a week (46.8\%) and 6 to $10 \mathrm{~h}$ was allotted for the cleaning of stud facilities (46.8\%). The data collected in the present study allow greater knowledge of this important part in the pig production chain in Brazil.
\end{abstract}

Key words: boar stud management, semen processing, semen quality.

Caracterização das centrais de coleta e processamento de sêmen no Brasil

RESUMO: O entendimento dos processos na suinocultura e como estes funcionam é fundamental para o incremento da performance reprodutiva. Por via eletrônica, foi realizada uma investigação com 32 centrais de coleta e processamento de sêmen no Brasil, representando 61,53\% do total no país. O número médio de reprodutores por central foi de 122. Reprodutores da linhagem comercial foram os mais frequentemente (59,38\%) utilizados nas centrais. As baias para alojamento individual dos reprodutores foram as mais comuns (71,9\%) e 81,25\% das centrais relataram possuir algum sistema de climatização. Na maioria das centrais (62,51\%), a média da concentração espermática foi maior que 200 milhões de espermatozoides/mL. Da mesma forma, a maioria das centrais (71,88\%) apresentaram um volume do ejaculado superior a $250 \mathrm{~mL}$. Em 46,88\% das centrais um ejaculado produziu de 26 a 40 doses inseminantes. Em 6,25\% das centrais eram utilizadas uma concentração de 3,5 bilhões de espermatozoides por dose inseminante na inseminação intracervical. A concentração espermática em 46,88\% das centrais era determinada através do sistema CASA. A avaliação da qualidade espermática era realizada através da análise de morfologia, concentração e exame microbiológico das doses inseminantes. Os colaboradores envolvidos com a coleta de sêmen tinham nível de instrução fundamental $(43,38 \%)$ e médio (37,5\%). A maioria dos técnicos no laboratório das centrais tinham ensino médio (75\%). A atividade que mais consumia tempo foi o processamento do sêmen, com 16 a 25 horas/semana (46,8\%) e 6 a 10 horas era utilizada na limpeza das instalações (46,8\%). Os dados coletados no presente estudo permitem um maior conhecimento desse elo da cadeia produtiva da suinocultura no Brasil. Palavras-chave: manejo do reprodutor, processamento de sêmen, qualidade seminal.

\section{INTRODUCTION}

Pork production in Brazil is one of the most important sectors of economy and the country is the fourth biggest exporter worldwide (ABPA, 2018). Artificial insemination (AI) is commonly used in the swine production system in Brazil (BORTOLOZZO et al., 2015), and estimates indicate that approximately 9.5 million semen doses are produced per year (BENNEMANN et al., 2018).
However, there is substantial variability in the reproductive performance of sows. This variation can be attributed to a number of factors such as the health of the inseminated sow (VARGAS et al., 2009), time of insemination (BORTOLOZZO et al., 2005) and the quality semen doses (SCHULZE et al. 2015; POPWELL and FLOWERS, 2004). The reproductive management of females is widespread and has been extensively researched. However, data on boar studs are scarce and often confidential. Genetic 
improvement of boars has been widely discussed and investigated to optimize the spread of highly valuable genes to improve reproductive efficiency in pig production (KNOX et al., 2008). Understanding boar management, the environment and facilities in boar studs, and the equipment and techniques used for semen collection and processing is necessary for discussing and developing tools to improve the use of genetics to increase the reproductive performance of boars. This article presented an overview of the main characteristics of boar studs in Brazil.

\section{MATERIALS AND METHODS}

We used an electronic, online survey tool to gather information from boar studs. A questionnaire created using Survey Monkey ${ }^{\mathrm{TM}}$ software (www. surveymonkey.com) was sent to managers from boar studs registered at the Ministry of Agriculture, Livestock and Supply (MAPA) in Brazil. Participation in the survey was voluntary and confidential, and only one questionnaire entry was allowed per boar stud. The survey had 92 closed-ended and multiplechoice questions distributed across topics ranging from facilities, genetic lines, boar replacement, and semen collection and processing, as well as sanitary and general management, production workflow and quality control of the semen dose.

This survey included 32 boar studs registered at the MAPA. These boar studs were located in the states of Rio Grande do Sul $(n=4)$, Santa Catarina $(n=14)$, Paraná $(n=6)$, Mato Grosso do Sul $(n=1)$, Mato Grosso $(n=2)$, Goiás $(n=2)$ and Minas Gerais $(\mathrm{n}=3)$.

\section{RESULTS AND DISCUSSION}

\section{Number of boars}

A total of 3,960 boars distributed through 32 boar studs, representing $61.53 \%$ of all boar studs registered by MAPA in 2015, were surveyed. The average number of boars per stud was 122 animals, with the highest frequencies of boars ranging from 51 to $80(28.1 \%)$ and 201 to $300(21.8 \%)$ in each facility. Only one boar stud housed more than 300 animals, six housed up to 50 boars, and 11 boar studs had more than 150 boars in production. These data demonstrated that the spread of valuable genes is concentrated in a few studs with a high density of boars. This feature of the boar production system provides a good opportunity for standardizing semen doses. However, it requires a stringent and continually audited biosafety program, because health and sanitary issues play a major role in semen production and the yield of semen doses. Strategically, the concept of high-yield boar studs might not be ideal because in the event of a sanitary emergency, for instance, it would have considerable consequences on semen sales and delivery.

\section{Common features of studs}

The breed used in $59.38 \%$ of the studs was a commercial line (Figure 1). However, 40.62\% of boar studs housed great grandparent (GGP) and grandparent (GP) breeding stocks along with commercial lines so that the studs had a mixed commercial and multiplier purpose (Figure 1).

Out of 32 boar studs, $62.50 \%$ were designed to meet the requirements of closed AI programs. The remainder of studs $(37.5 \%)$ were developed from collaborative projects between the private and public sectors to meet the demand for semen from open AI programs. Overall, $50 \%$ of boar studs use only one genetic line with only $12.50 \%$ of the studs housing more than three genetic lines. This feature has been observed in open semen production systems for semen sales to meet the end customer's needs.

Boar lineages varied among studs (Figure 2) representing the main AI swine genetics companies (Agroceres PIC-Genetiporc ${ }^{\circledR}$, Topigs Norswing $^{\circledR}$ and DB Danbred $\left.{ }^{\circledR}\right)$. Nevertheless, there was a predominance of $\mathrm{AG} 337^{\circledR}$ in $64.52 \%$ of the studs. The other lines used were $A G 1020^{\circledR}(19.3 \%)$, G Performer $6^{\circledR}(16.1 \%)$, G Performer $8^{\circledR}(12.9 \%)$, AG1010 (12.9\%), AG1075 ${ }^{\circledR}$ (3.23\%), LM6200 ${ }^{\circledR}$ (9.7\%), and LI7600 ${ }^{\circledR}(9.7 \%)$.

The average age of boars was 17.9 months of age, while $12.5 \%$ of the sires were between 24 and 30 months of age. No stud had boars that were below 12 or above 30 months of age. The annual boar culling rate ranged from $60 \%$ in $54.84 \%$ of the studs to $80 \%$ in $12.9 \%$ of the studs. About $50 \%$ of the culled boars were 22 months of age or older. High boar replacement rates suggested an efficient genetic improvement program, especially in studs that house GP and GGP breeding stocks. According to KNOX, et al. (2008), boar culling and replacement in North American studs ranged widely, from 20 to $70 \%$. Their survey identified genetic improvement as the main reason for boar replacement.

\section{Reasons for boar culling and replacement}

The most important reasons mentioned for boar culling were lameness $(32.26 \%)$, genetic improvement (29.03\%), poor health (29.03\%), seminal quality (25.81, and genetic replacement (19.35\%) (Figure 3). Approximately $62 \%$ of boars 


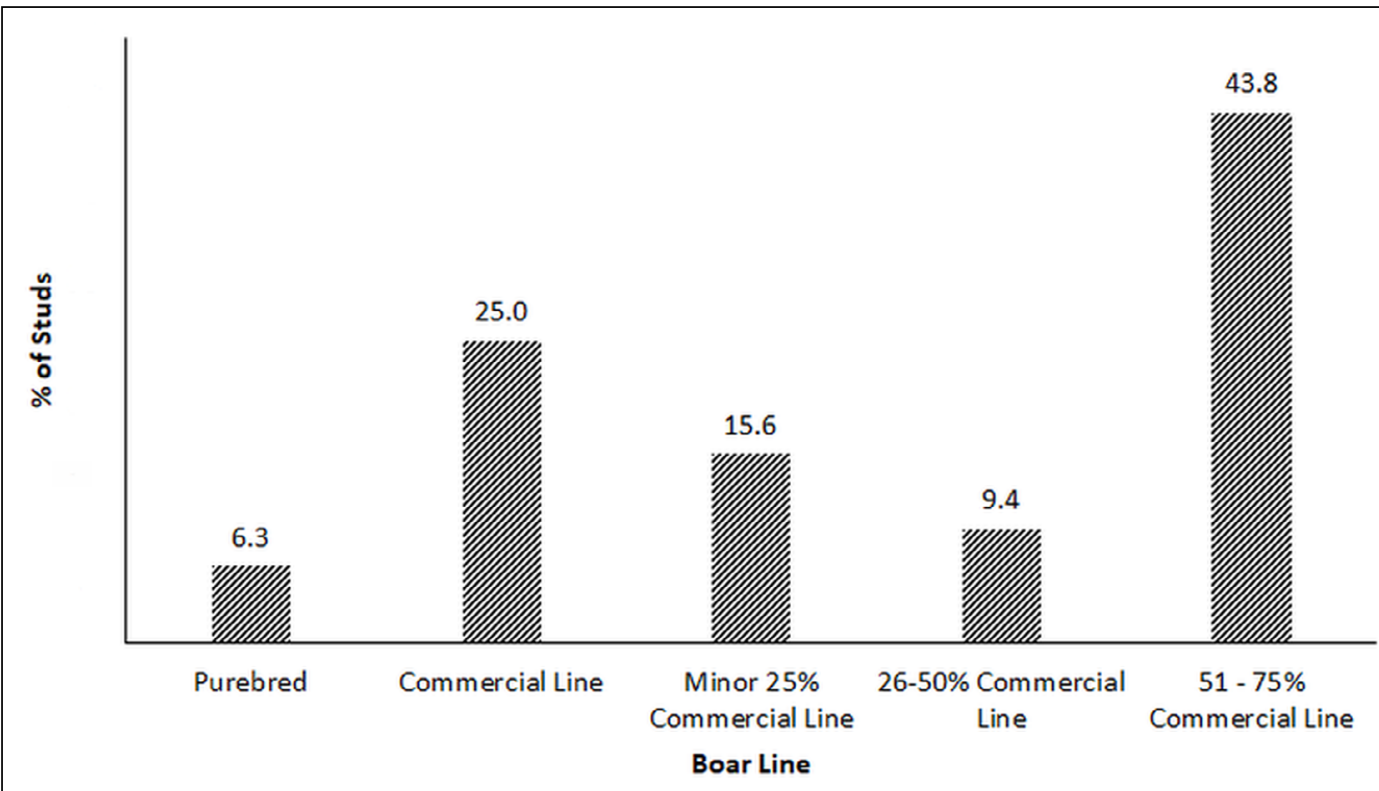

Figure 1 - Percent distribution of genetic lines (purebred and commercial line boars) for 32 Brazilian boar studs.

selected for culling were submitted to immuno castration (Vivax ${ }^{\circledR}$, Zoetis). Often, locomotor disorders are associated with flooring and housing, as $71.87 \%$ of the boar studs use individual pens as the predominant housing system. Movement restriction combined with improper flooring might lead to feet and leg issues. KNOX et al. (2008) reported that $81 \%$ of boar replacement was due to limb disorders.

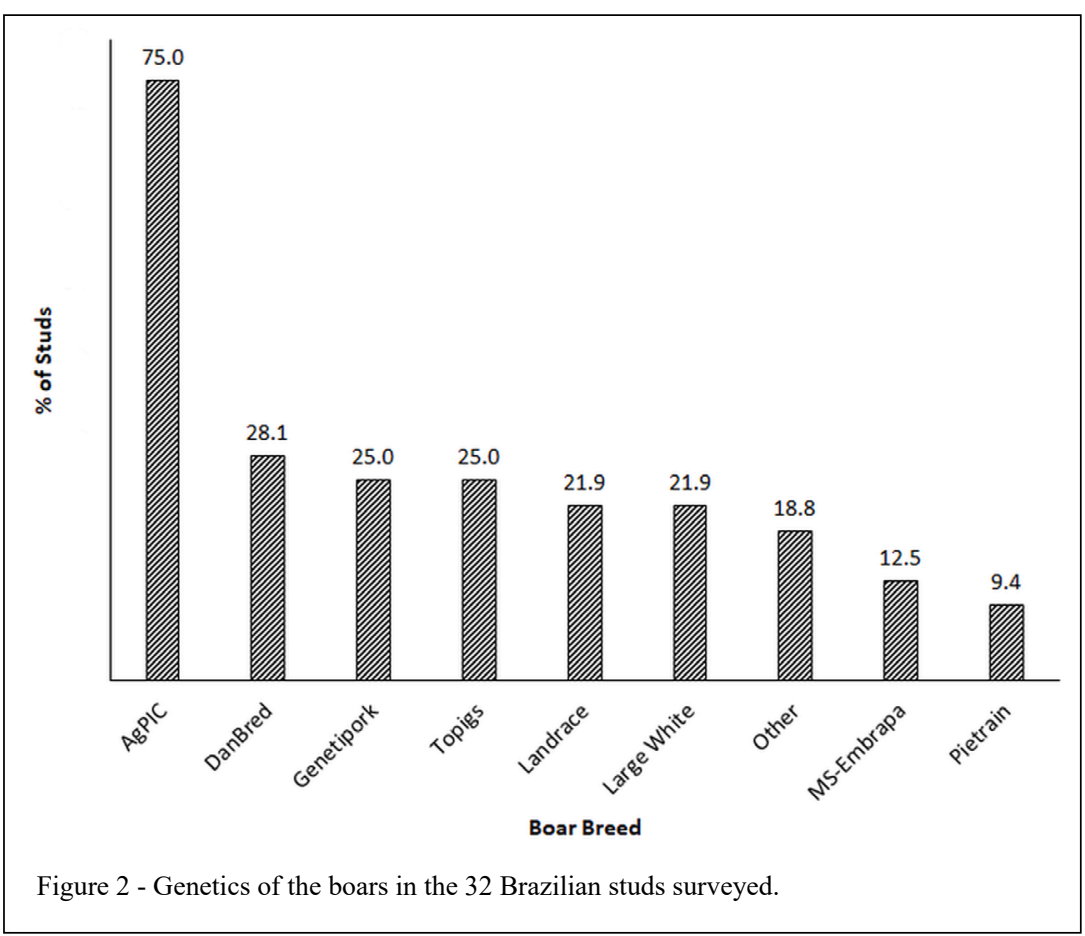

Ciência Rural, v.50, n.11, 2020. 


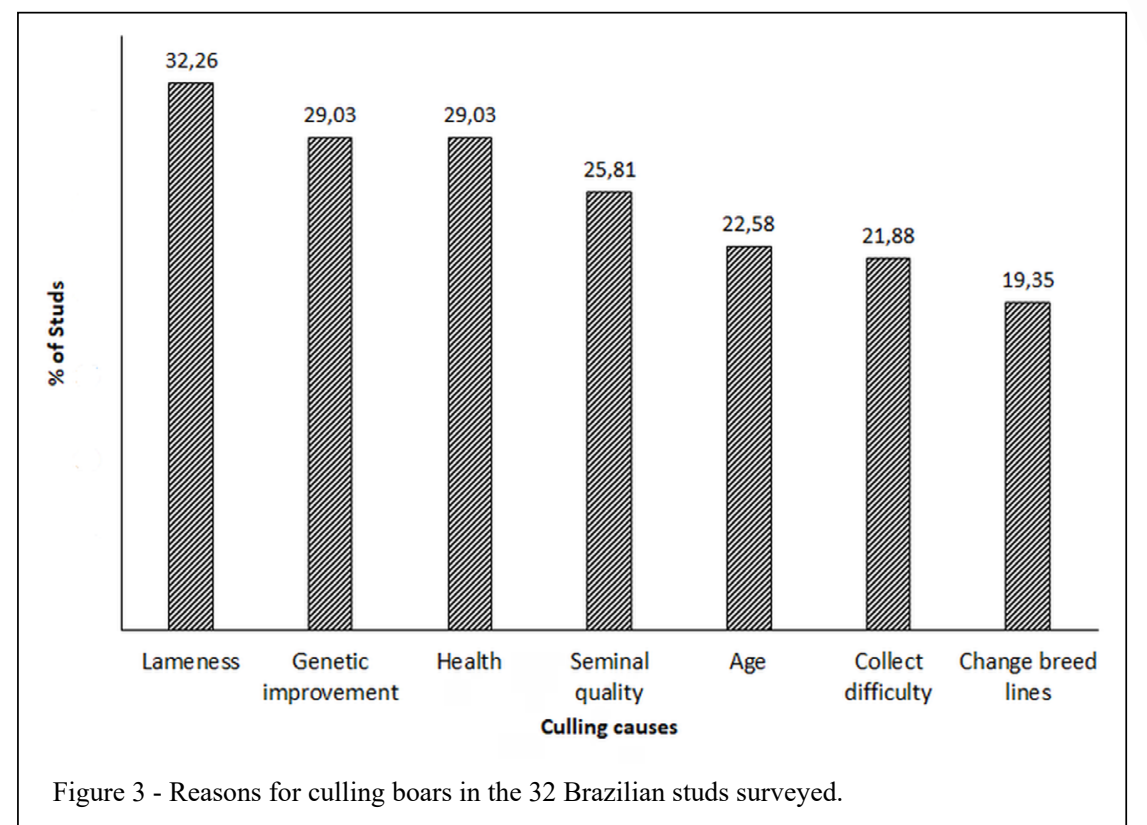

\section{Causes of boar mortality}

The average annual boar mortality rate was $3.9 \%$. However, for $43.75 \%$ of the studs, this rate was as low as $3 \%$. These numbers suggested an overall well-managed herd considering that $81.25 \%$ of the studs had some thermal control system. The most important causes of boar mortality were respiratory disease (41.93\%), culling of unhealthy animals $(46.88 \%)$, and gastric ulcers $(38.71 \%)$.

\section{Facilities}

The majority $(81.25 \%)$ of studs reported had some kind of thermal control system (Table 1). Individual pens and stalls were the most common housing system used (71.9\%). However, it was noticed that there is growing attention to well-being as $28.1 \%$ of the studs used only individual pens. A combination of slatted (1/3) and solid (2/3) flooring were the main choices in $68.7 \%$ of the studs (Table 1). The studs surveyed did not show agreement with respect to feeding systems: both manual and automated systems were widely used. Water delivery in studs was accomplished mostly (59.4\%) through nipples. The number of semen collection areas varied from one to more than seven per stud. However, most boar studs had up to three semen collection areas. Only one stud had more than seven collection areas. We observed that there is a perceptible evolution in the semen collection technology being used as $40 \%$ of the studs use at least one dummy for semi-automatic collection, enabling very little operator interference, and $32 \%$ of the studs use four to five separate pens to collect semen.

\section{Semen production}

The average sperm concentration per $\mathrm{mL}$ of semen was higher than 200 million in $62.51 \%$ of the studs (Figure 4) and the average ejaculate

Table 1 - Specific features and response categories of the building environment of studs.

\begin{tabular}{|c|c|c|c|c|}
\hline Features & ------------------ & -------Response Categories & 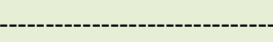 & . \\
\hline Cooling & Evaporative (53.1\%) & Nebulizers and fans (15.6\%) & Fans $(12.5 \%)$ & None $(18.75 \%)$ \\
\hline Housing & $100 \%$ Pens $(28.1 \%)$ & $10 \%$ Stalls $(34.4 \%)$ & $11-40 \%$ Stalls $(37.5 \%)$ & - \\
\hline Flooring & $100 \%$ Solid $(9.4 \%)$ & $100 \%$ Slatted $(21.9 \%)$ & 1/3 Slatted (68.7\%) & - \\
\hline Feeding & Drop feeders $(46.9 \%)$ & Hand fed $(53.1 \%)$ & - & - \\
\hline Water delivery & Troughs (34.4\%) & Nipples (59.4\%) & Cups $(6.25 \%)$ & - \\
\hline
\end{tabular}

Ciência Rural, v.50, n.11, 2020. 


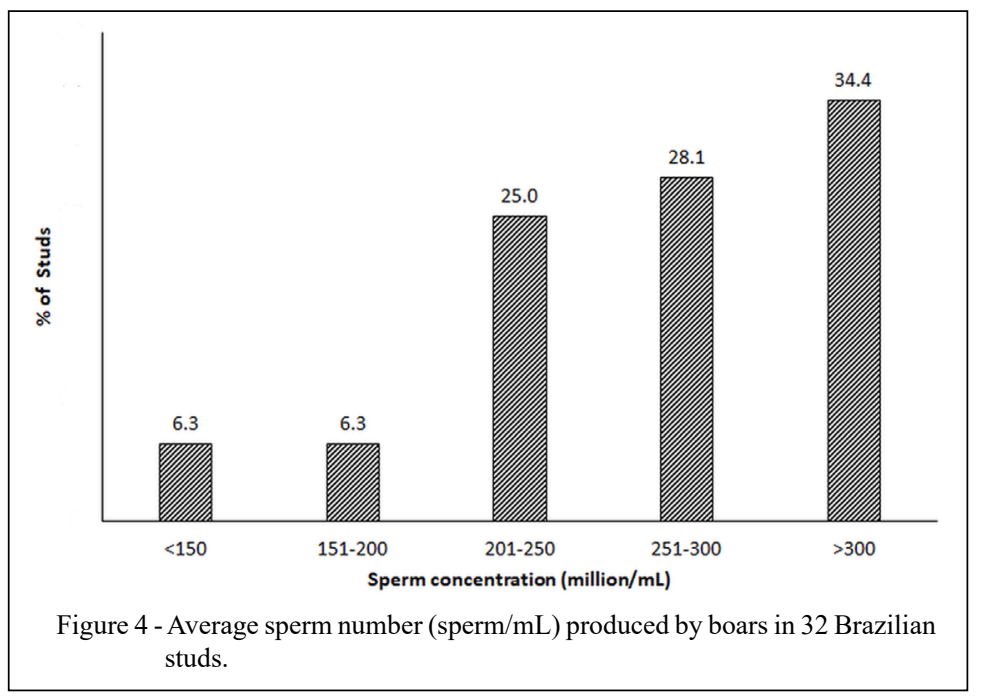

volume was more than $250 \mathrm{~mL}$ in $71.88 \%$ of the studs (Figure 5). We observed substantial variation among studs regarding the frequency of semen collection for fully grown males (more than 18 months old). In $65.6 \%$ of the studs, resting varied from five to seven days, regardless of boar age. One collection per week was used as a standard in a number of studs to maintain a high concentration of sperm in every collection, which enables a higher number of inseminating doses per ejaculate. The frequency of semen collection according to boar age is no longer a common practice, for $71.88 \%$ of boar studs carried out semen collection within, at least, a 5-day interval, regardless of boar age.
Regarding the number of semen doses produced in each ejaculate, $46.88 \%$ of the studs ranged from 26 to 40 inseminating doses. However, $25 \%$ of the studs produced more than 40 inseminating doses. Up to 25 semen doses were produced in $28.13 \%$ of the studs, with a total of three billion sperm cells in each dose in $56.25 \%$ of the studs. In $6.25 \%$ of the studs, 3.5 billion sperm cells per dose were used in intracervical AI. Only $31.2 \%$ of the studs used doses containing two billion sperm cells per dose or less. The post-cervical AI technique compelled most prominent studs to shift towards a system with better control of sperm concentration; thereby, reducing the number of sperm for AI to 1.5-2 billion cells per dose.

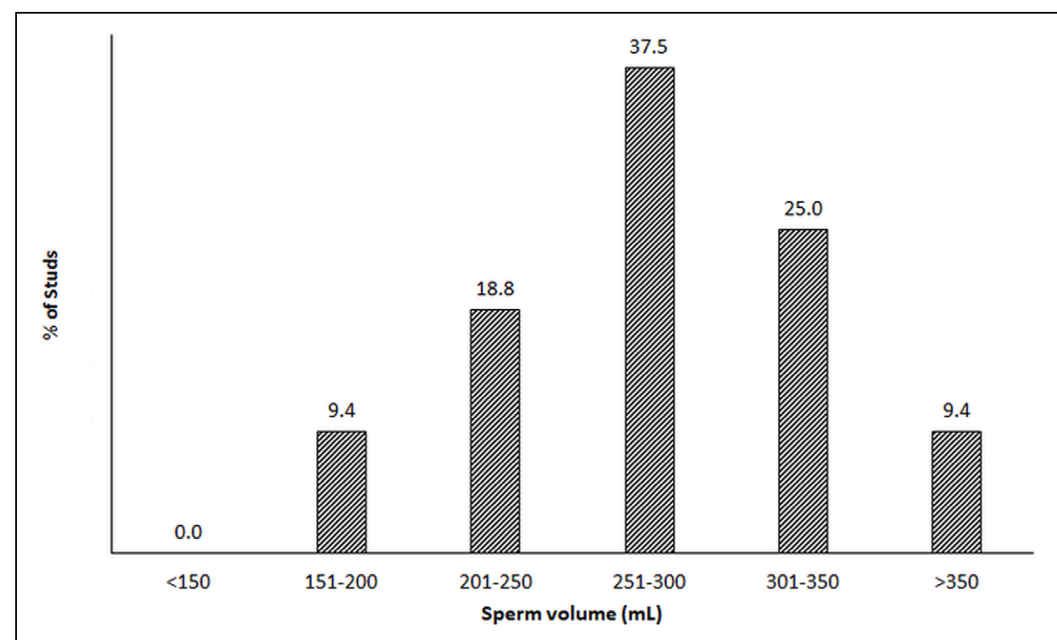

Figure 5 - Average semen volume per ejaculate of boars in the 32 Brazilian studs surveyed.

Ciência Rural, v.50, n.11, 2020. 


\section{Collection and semen processing}

\section{Boar training}

A 40 to $80 \%$ replacement rate was observed in $56.23 \%$ of the studs. All studs surveyed outsourced boars for replacement. Boars were introduced into studs 4-6 times a year (59.38\%) after being quarantined. The age of the boars at the beginning of semen collection training ranged from 161 to 190 days at $50 \%$ of the studs. However, in $37.50 \%$ of the studs this management started at 191 to 220 days of age. Most (68.75\%) of the time, the training was conducted at the stud that the boars were housed at. Only $31.25 \%$ of the studs started the semen collection training during the quarantine period. Young boars were trained twice a week in $54.84 \%$ of the studs, and in $32.26 \%$ of the studs training frequency was 3 to 4 times a week.

\section{Semen collection}

The overall design of the boar studs followed strict guidelines and procedures for worker safety, boar well-being, animal management efficiency and semen collection (GALL, 2000). In $68.75 \%$ of the studs, there was an adjacent pit for the operator (about 0.8-1 m deep) as part of the basic design of the semen collection area. This design, being the most commonly used construction form at studs, allowed an ergonomically friendly posture for the semen collector. Only $18.75 \%$ of the studs used semen collection stalls with a compact floor.

Semen collection was performed by only 2 people in $50 \%$ of the studs, and in $21.88 \%$ of the studs it was performed by 3 to 4 people. The semen collection regimen allowed processing of about three to four boars per hour in $50 \%$ of the studs, and 11 to 15 boars in a single day in $40.63 \%$ of the studs. In $40 \%$ of the studs, at least one semen collection area had an automated or semi-automated dummy. Thus, in $38.7 \%$ of the studs, one person performed two semen collections at the same time. In $45.16 \%$ of the studs, each employee attended to a single boar at a time.

\section{Semen collection methods}

Double gloving was used in most $(62.5 \%)$ of the studs to collect boar semen. When the doublegloving method was employed on both hands, the outer pair of gloves was discarded following semen collection. In $34.4 \%$ of the studs, double gloving was only used on one hand, and the outer glove was removed after preputial cleaning.

The preputial diverticulum was cleaned prior to semen collection in a pre-collection area at most studs $(62.50 \%)$ or in the collection area in some studs $(34.38 \%)$. In $90.63 \%$ of the studs, preputial hair trimming was considered a risk factor for sperm contamination. According to GOLDBERG et al. (2013), bacterial contamination of the ejaculate increases up to four times when high standards of hygiene - including cleaning of the preputial area, hair trimming, and glove care procedures - are disregarded.

With respect to the semen collection material used, there was little variation among the studs, with $43.75 \%$ of the studs using an isothermal recipient fitted with a disposable plastic cup collector and filter, while $50 \%$ of the studs used a disposable plastic bag in an isothermal cup and filter.

The most frequent $(65.63 \%)$ semen collection interval at studs was five to seven days. The average number of collections performed per week was subdivided according to the age of the males. Boars of up to eight months of age were collected once a week at almost all $(90.63 \%)$ of the studs and older males between 9 and 18 months of age were collected 1.2 to 1.5 a week at half of the studs (Table 2). Similar management was observed in many $(40.63 \%)$ studs in boars of 19 to 25 months of age (Table 2). Regarding semen collection, total ejaculate was collected in $62.50 \%$ of the studs and in $37.50 \%$ of the studs, only the sperm-rich fraction was collected discarding the other fractions of the ejaculate.

\section{Semen processing and evaluation}

Semen processing took 16-25 hours a week in $46.88 \%$ of the studs. The raw ejaculate volume was predominantly estimated by weight, measured on a precision scale ( $1 \mathrm{~g})$, immediately after collection (96.67\%). On average, the raw semen volume ranged from 251 to $300 \mathrm{~mL}$ in $37.50 \%$ of the studs.

In $25 \%$ of the studs the evaluation of sperm motility was carried out in an extender after a predilution (1:1) of the ejaculate sample. In $18.75 \%$ of the studs, sperm motility was assessed using phase-contrast microscopy, in $34.38 \%$ of the studs it was assessed using bright field microscope and in $46.88 \%$ of the studs is was assessed using computer-assisted system analysis (CASA). Also, in $29.63 \%$ of the studs, sperm analysis was performed subjectively in phase contrast or bright field microscopy, with a total magnification of $100 \mathrm{x}$. All slides were heated in a thermal block before use in almost all $(96.77 \%)$ of the studs.

Sperm concentration was determined using CASA in $46.88 \%$ of the studs, while $34.38 \%$ of the studs used a photocolorimeter. Average concentrations ranged from 251 to 300 million sperm $/ \mathrm{mL}$ in $28.13 \%$ of the studs and $>300$ million sperm $/ \mathrm{mL}$ in $34.38 \%$ of the studs. The technical advancement of semen 
Table 2 - Weekly semen collection frequency (average percent) carried out according to boar age.

\begin{tabular}{|c|c|c|c|c|}
\hline \multirow[t]{2}{*}{ Boar age (months) } & \multicolumn{4}{|c|}{ 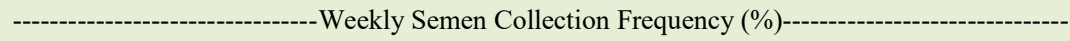 } \\
\hline & 1.0 & $1.2-1.5$ & $1.6-2.0$ & $>2.0$ \\
\hline 8 & 90.63 & 6.25 & 3.13 & 0.00 \\
\hline $9-12$ & 43.3 & 50.0 & 6.67 & 0.00 \\
\hline $13-18$ & 18.75 & 50.0 & 28.13 & 3.13 \\
\hline $19-25$ & 9.38 & 40.63 & 43.75 & 6.25 \\
\hline$>25$ & 16.13 & 38.71 & 38.71 & 6.45 \\
\hline
\end{tabular}

processing has allowed more precise evaluation of sperm using computer-based systems. Consequently, it enabled a highly precise analysis of motility and sperm concentration, setting high standards of quality for large scale production of semen doses.

Discard rates for predilution ejaculates were up to $5 \%$ in $65.63 \%$ of the studs, and 6 to $10 \%$ in $25 \%$ of the studs surveyed. In $9.37 \%$ of the studs, the ejaculate was not disposed of in the microscopic analysis. In addition, $34.38 \%$ of the studs did not discard the ejaculate after dilution and $62.5 \%$ of the studs discarded up to 5\%. Elimination of improper ejaculates is paramount to ensure the quality of semen doses. It is expected that approximately $5 \%$ of the ejaculates are disposed of for insufficient quality either during in natura evaluation or after dilution. The time spent to perform a seminal microscopic analysis was up to 60 seconds in $71.36 \%$ of the studs.

\section{Semen packaging and delivery}

The number of semen doses processed per ejaculate considered the number of viable sperm in $45.16 \%$ of the studs, while $35.48 \%$ of the studs considered the total number of sperm in the ejaculate. This evaluation criterion is important when the concentration of the dose needs to be appraised and standard procedures are necessary to keep acceptable quality control. The most frequent volume of semen dose that was adopted was $50 \mathrm{~mL}$ for studs that employed post cervical insemination $(43.75 \%)$ and 81 to $90 \mathrm{~mL}$ for studs that used intra-cervical insemination $(34.38 \%)$ ). Half of the studs used shortterm (72-96 hours) and $37.5 \%$ of the studs used long-term (more than 96 hours) extenders. There is a current trend towards the use of long-term extenders that allow a longer storage time even in samples intended for immediate use.

In most $(84.38 \%)$ of the studs, the extender in powder form was reconstituted in heated stainless- steel tanks. A reverse osmosis system was employed to produce purified water to reconstitute the extenders in $90.63 \%$ of the studs. Manual semen extension utilizing dilution jars and disposable plastic bags was accomplished in $65.63 \%$ of the studs, followed by the use of a semi-automated system equipped with sturdy plastic cylinders ( $25 \%$ of the studs). Half of the studs did not use pooled semen as the individual performance of the boars was considered important. Moreover, there was a perception in $21.8 \%$ of the studs that sperm pooling improves neither value nor quality of the dose. Pooling two and three ejaculates was preferred by $9.4 \%$ and $3.1 \%$ of the studs, respectively. Sperm pooling is a suitable possibility to avoid creating genetic subpopulations and their negative effects on the reproductive performance of the herd (VICENTE-FIEL et al. 2013).

Automatic packaging in blisters (Magapor $^{\mathrm{TM}}$, Zaragoza, Spain) sealed automatically was used in $50 \%$ of the studs. In addition, a semiautomated system using see-through Flexitubes (Minitube GnbH, Thiefenbach, Germany) sealed in semi-automated sealers was preferred by $40 \%$ of the studs. In $48.4 \%$ of the studs, the insemination doses were shipped to the final consumer immediately after packaging. The doses were stored for $24-47 \mathrm{~h}$ in $38.7 \%$ of the studs and $6.45 \%$ kept the doses for $>$ $96 \mathrm{~h}$. Weekly production of semen doses ranged from $501-1,000$ in $9.38 \%$ of the studs to 5,000 in $25 \%$ of the studs.

Transport of the doses to the sow farm was by road in containers with programmable temperature control $\left(15-18{ }^{\circ} \mathrm{C}\right)$ for $58.06 \%$ of the studs, and it was done in Styrofoam boxes without an accurate temperature control system for $22.58 \%$ of the studs. For $37.5 \%$ of the studs, the distance between the studs and the sow farms varied from 51-100 km. Only one stud shipped semen samples a distance over $600 \mathrm{~km}$. Transport quality was monitored either through a data 
logger $(37.5 \%)$ or a minimum-maximum thermometer $(28.13 \%)$ in most of the studs. Temperature control during transport is indispensable for the maintenance of the quality of the inseminating dose. Shipment of semen lacking appropriate temperature control may be associated with reduction in storing time of the extended semen. According to ROZEBOON (2003), temperature fluctuations of $\pm 2-3^{\circ} \mathrm{C}$, sperm viability and shelf live were decreased by at least one day.

\section{Quality control of the doses}

The assessment of sperm quality was conducted using morphology, concentration, and microbiological testing. Sperm morphology assessment of all boars was routinely carried out in the majority $(85.5 \%)$ of studs. Some $(38.71 \%)$ of these analyses were performed in the studs where the semen was collected, while most (61.29\%) of the exams were outsourced. The frequency of these exams ranged from every 30 days $(32.26 \%$ of the studs) to every 60 days ( $38.71 \%$ of the studs) and two studs performed these analyses in freshly introduced males.

The analysis of sperm concentration was conducted using CASA in $50 \%$ of the studs, in $34.38 \%$ of the studs a Neubauer Improved ${ }^{\circledR}$ chamber was used and in $9.38 \%$ of the studs this assessment was not conducted. In $87.1 \%$ of the studs, microbiological control of the semen doses and raw semen, extender, and purified water was conducted, on a monthly basis.

\section{Labor features}

Semen collection and evaluation/semen processing required two to four employees in $71.8 \%$ and $65.6 \%$ of the studs, respectively. Employees working on semen collection had formal education of elementary/middle school (34.38\%) and high school (37.5\%). From the employees working in the laboratory setting, $75 \%$ had frequented high school and $15.63 \%$ had higher education, including the American equivalent to undergraduate and graduate schools.

The current technology adopted for processing boar semen has demanded a solid understanding of these techniques, so sufficient capacity and formal education, including continuing the education of employees has become relevant. Production of quality semen doses is a key in the pork production chain because low-quality semen is highly detrimental to the profitability of operations. Hiring specialized labor is justified in a stud as the activities conducted in a stud require strict attention to detail as well as careful observation of potential discrepancies in any of the processes. The most prevalent employee turnover rate was up to $5 \%$ for both staff involved in semen collection, in $71.88 \%$ of the studs, and the laboratory, in $76.67 \%$ of the studs.

\section{Labor and time allotment on general stud tasks}

The most time-consuming task undertaken at studs was semen processing, taking 16 to $25 \mathrm{~h}$ a week at $46.8 \%$ of the studs. A time between 6 and $10 \mathrm{~h}$ was allotted for cleaning of the facilities (stalls and laboratories) in $46.8 \%$ of the studs. Additional activities such as animal transfer within facilities, health treatments, training and feeding the boars each took one to five hours a week (Table 3). Similarly, KNOX et al. (2008) observed that a substantial amount of the time is spent on veterinary care and equipment maintenance. According to these authors there were more variability in time used moving the animals, feeding, and cleaning the facilities. Therefore, a clear rationale for priority management is key to define production flow strategies.

Table 3 - Percentage of hours spent conducting each task by stud employees during a 40-hour workweek.

\begin{tabular}{lcccccc}
\hline Variable & & & & & & \\
& - & & & & \\
& $0 \mathrm{~h}(\%)$ & $1-5 \mathrm{~h}(\%)$ & $6-10 \mathrm{~h}(\%)$ & $11-15 \mathrm{~h}(\%)$ & $16-25 \mathrm{~h}(\%)$ & $>25 \mathrm{~h}(\%)$ \\
\hline Animal health & 3.13 & 90.63 & 6.25 & 0.00 & 0.00 & 0.00 \\
\hline Feeding boars & 9.38 & 59.38 & 18.75 & 12.50 & 0.00 & 0.00 \\
Moving boars & 0.00 & 50.00 & 31.25 & 12.50 & 3.13 & 3.13 \\
Cleaning (stalls and lab) & 0.00 & 18.75 & 46.88 & 18.75 & 15.63 & 0.00 \\
Semen processing & 0.00 & 6.25 & 9.38 & 25.00 & 46.88 & 12.50 \\
Training young boars & 0.00 & 59.38 & 25.00 & 12.50 & 0.00 & 3.13 \\
\hline
\end{tabular}

Ciência Rural, v.50, n.11, 2020. 


\section{CONCLUSION}

Some features such as use of a commercial line, closed AI programs, age of boars, use of individual pens, rate of replacement, and semen processing quality control were commonly observed, whereas feeding system, building environment setup, and boar breed varied substantially among studs. Boar studs have become increasingly important in the strategic management of the swine production chain. The rapid spread of highly valuable genes, as well as the quality of semen doses is decisive for improved reproductive and productive performance. Thus, a proper understanding of the work routine is important to enable the use of new management systems, equipment and semen processing techniques.

\section{ACKNOWLEDGEMENTS}

The authors are thankful to all companies that participated for providing the data.

\section{DECLARATION OF CONFLICTS OF INTERESTS}

The authors declare no conflict of interest. The founding sponsors had no role in the design of the study; in the collection, analyses, or interpretation of data; in the writing of the manuscript, and in the decision to publish the results.

\section{FUNDING}

This study was funded in part by the Coordenação de Aperfeiçoamento de Pessoal de Nível Superior - Brasil (CAPES) - Funding Code 001

\section{AUTHORS' CONTRIBUTIONS}

PEB, JFMB and SAM conceived and designed experiments, carried out the descriptive analyses, prepared the draft of the manuscript and approved of the final version. MW and JB prepared the draft and critically revised the manuscript.

\section{REFERENCES}

ABPA - Associação Brasileira de Proteína Animal. 2018. Relatório Annual, 2018. Available from: <http://abpa-br.com.br/storage/ files/relatorio-anual-2018.pdf>. Accessed: Dec. 13, 2019.

BENNEMANN, P.E. et al. Bacterial contaminants and antimicrobial susceptibility profile of boar semen in southern
Brazil studs. Revista MVZ Córdoba. v.23, n.2, p.6637, 2018. Available from: <https://revistas.unicordoba.edu.co/index.php/ revistamvz/article/view/1338/pdf $>$. Accessed: Nov. 28, 2019. doi: $10.21897 /$ rmvz.1338

BORTOLOZZO, F.P., et al. New Artificial Insemination Technologies for Swine. Reproduction in Domestic Animals. v.50, p.80-84, 2015. Available from: <https://www.ncbi.nlm.nih. gov/pubmed/26174923>. Accessed: Oct. 12, 2019. doi: 10.1111/ rda. 12544.

BORTOLOZZO, F.P., et al. Influence of time of insemination relative to ovulation and frequency of insemination on gilt fertility. Theriogenology. v.64, n.9, p.1956-1962, 2005. Available from: $<$ https://www.ncbi.nlm.nih.gov/pubmed/16005953> Accessed: Nov. 18, 2019. doi: 10.1016/j.theriogenology.2005.04.023.

GOLDBERG, A.M. et al. Risk factors for bacterial contamination during boar semen collection. Research in Veterinary Science. v.95, n.2, p.362-367, 2013. Available from:<https://www.ncbi. nlm.nih.gov/pubmed/23891384> Accessed: Nov. 28, 2019. doi: 10.1016/j.rvsc.2013.06.022

GALL, T. Boar stud design as it relates to functionality. Boar Semen Preservation IV, Allen Press, Lawrence KS, p. 199205, 2000

KNOX, R., et al. An update on North American boar stud practices. Theriogenology. v.70, n.8, p.1202-1208, 2008. Available from: $<$ https://www.ncbi.nlm.nih.gov/pubmed/18656252>. Accessed: Nov. 28, 2019. doi: 10.1016/j.theriogenology.2008.06.036.

Ministério da Agricultura, Pecuária e do Abastecimento, 2015. Estatísticas do material Genético. Available from: <www. agricultura.gov.br/animal/material-genetico/estatisticas $>$. Accessed: Dec. 15, 2015.

ROZEBOON, KJ. Quality assurance of semen. In: Allen D. Leman Swine Conference, 2003, Saint Paul, Proceedings..., Saint Paul, MN. P. 171-179. Available from: <http://hdl.handle. net/11299/146366>. Accessed: May, 6, 2020.

SCHULZE, M. Analysis of hygienic critical points in boar semen production. Theriogenology. v.83, p.430-437, 2015. Available from: $\quad<$ https://www.ncbi.nlm.nih.gov/pubmed/25459424> Accessed: Nov. 28. 10.1016/j.theriogenology.2014.10.004.

VARGAS, A.J. Factors associated with return to estrus in first service swine females. Prev Vet Med. v.89, n.1-2, p.7580, 2009. Available from: <https://www.ncbi.nlm.nih.gov/ pubmed/19304332>. Accessed: Jun. 11, 2019. doi: 10.1016/j. prevetmed.2009.02.001

VICENTE-FIEL. S. et al. A comparative study of sperm morphometric subpopulations in cattle, goat, sheep and pigs using a computer-assisted fluorescence method (CASMA-F), Animal Reproduction Science. v.139, p.182-189, 2013. Available from: $<$ https://www.ncbi.nlm.nih.gov/pubmed/23642499>. Accessed: Oct. 18, 2019. doi: 10.1016/j.anireprosci.2013.04.002. 